\title{
The Image of History as Artistic Dominant of the Urban Environment
}

\author{
Mikhail Dutsev ${ }^{1, *}$ \\ ${ }^{1}$ Scientific Research Institute of the Theory and History of Architecture and Urban Planning, Branch of the \\ Federal State Budget Institution "Central Scientific-Research and Project Institute of the Construction Ministry \\ of Russia", Moscow, Russia \\ *Corresponding author. Email: nn2222@bk.ru
}

\begin{abstract}
The article is devoted to the problem of the artistic image in the historical city environment. Image of history is perhaps the most anticipated and developed context for the work of an architect, designer, or artist. At the same time, this resource has a clearly expressed "educational" character, preserving faith in the value of a material artifact and respect for the memory of the lost material. There are several actual manifestations of this resource: museumification, conservation, reconstruction of lost environmental fragments; contextualism and its versions; metaphors, symbols and archetypal meanings; immersion in the atmosphere of the past-creating a special aura; prolongation of history. A special facet is the idea of glocalization at the intersection of global trends and local traditions. Today, the concept of a "museum" is clearly not enough: understanding a living city is more viable. That is why the creation of a complete myth in the personal mental field of a person on the basis of personal history has a special artistic potential. The article offers a version of reading history in the modern city multilayered reality based on the author's concept of art integration in architecture.
\end{abstract}

Keywords: Urban environment, Context, Renovation, Historical city, Image, Myth, Art integration.

\section{INTRODUCTION}

Today's urban history is extremely controversial. In any case, what happens to the urban environment cannot but cause polar assessments - we often fall from one extreme to another. Today, the city as a system, as an organism, as a community is dramatic! The "city" is aggressive as a lifestyle. The city is extremely restless as a living habitat. The city is eclectic in artistic terms. The structure of the city, its spatial fabric is ragged, patchwork, many-sided, wonderful ... Unity is rather a myth than a manifested reality.

We are, of course, obliged to make such a most honest recognition in order to be able to see the range of problems of today's city, definitely, correlating the new, contemporary to us, with history - with its material heritage, image,

*Fund: This study is based on the research, supported by the Program of Fundamental Research of the Russian Academy of Architecture and Construction Sciences and of the Ministry of Construction, Housing and Utilities of the Russian Federation 2021. meaning, the idea of historicity as such, its relevance and viability. The protective tradition of the attitude to urban space is certainly valuable, but it is undergoing natural transformations. It is obvious that a museum-like city is an entertaining and informative "attraction", but not an environment of full-fledged life. After all, the city is always the closest accomplice of the happening eventfulness, the space that is lived in and experienced again and again [1]. To make history an integral part of modernity, even of the daily flow of life, while maintaining respect and an understandable time isolation, is not an easy task, but it is relevant. Otherwise we lose the historic city... We lose it physically when it is simply erased by the new time. We lose it mentally when it turns into a museum.

It seems that the connecting principle in the multidimensional field of a historical city is indeed the environment in various interpretations: the environmental approach, the environmental scenario, and the environmental unity. The concept of context has repeatedly helped and allowed to 
preserve the historical image of a place. There is probably no point in revising the "environmental" facets of professional consciousness, but there is a clear need to expand the concept and, as a result, to update the understanding of the city.

It is proposed to identify a number of grounds or directions of the desired development:

- integration of architecture, art and design;

- attention to the material and artistic realities of the city;

- enriching the culture of the professional community and society as a whole.

\section{THE IMAGE OF THE CITY: MYTH AND REALITY}

\begin{abstract}
Myths come and go, traveling from place to place. Each generation tells them differently, adding new to the heritage received from their
\end{abstract} fathers.

But behind this reality, which changes from era to era, there is another, stable reality, largely beyond the control of time [2].

Aldo Rossi. "The Architecture of the City". 19662.

The tendency of turning to the history and images of the past time is expected to be associated with the concept of the environment and is expressed in a combination of directions: museumification, reconstruction of lost environmental fragments, speaking metaphors, symbols and archetypal meanings, immersion in the atmosphere of the past - the creation of a special aura. This range can be expanded based on the diversity of today's scientific school of restoration. Special "border zones" of key importance should be emphasized in the aspect of the study of the realities of the historical city.

First of all, from the point of view of the viability of the environment, the resource of "lived" history is important, when the heritage and artifacts of the past are treated not as decorations, but as real accomplices of current events. Space and buildings reveal their full existence in several times, which is also transmitted into human perception [3]. A historical environment appears, enriched with living connections of the past with the present.

Prolongation of the historical image by sort of metaphysical way is not just recreation of the original motif, but immersion in the atmosphere [4] (G. Böhme) and (or) formation of the aura [5] (W.
Benjamin), that is, a complex of environmental hints that evoke feelings and premonitions. The aura should be understood as a kind of radiation, a shell that is spread outwards [6]. It surrounds a phenomenon or work and extends far beyond its limits - beyond spatial, temporal, and disciplinary boundaries. In this way, we are able to "catch" the rays of the aura of the long-past or even practically unknown to us only by individual evidence, details, indirect facts and, most importantly, images-echoes living in history and the field of culture and transmitted through complex chains. In certain sense, everything has an aura or acquires it. I would like to believe that the focus on creating and preserving the aura even more than the atmosphere will help to overcome the problems of the consumer attitude to the world of each individual representative of society, and will also become a saving link in the process of restoring the integrity of cultural and civilizational ties. The most poetic direction that connects the space and a resident or a guest is to follow the feelings of a person [7].

Any city in our perception (consciousness, memory, imagination) is always represented between myth and reality. The city is a real mythology and a "mythological" (mythologized in centuries and being mythologized now) reality. We readily understand and accept that an architectural space cannot be considered complete without being accompanied by meaning and fiction addressed to a person ... The entire aggregate space of the city must live! However, the artificial "revival" of historical places is just as ridiculous as the oblivion of them. It is necessary to remember seemingly an immutable truth: the city is made up of many-sided and different-time buildings, man-made and nonman-made spaces, events, and people. It lives the lives of its inhabitants. Therefore, the greatest value is acquired by such an environment of life in which the possibilities of realizing the personal history of each person are preserved. The history that is tied up with time along its whole period.

It makes sense to consider some of the opinions of architectural theorists about the mythological essence of the city. Thus, A. Rossi, quoted in the epigraph, recognized in his statements the absolute value of the revealed reality, its material truth. It is no accident that the future master gives such titles to the chapters of his book "The Architecture of the City": "The individuality of urban artifacts" or "The urban artifact as a work of art". However, paradoxically the architect built his creative method almost entirely on the facts of personal history with the priority of personal artistic reality over the 
context of the place. P. Eisenman also draws attention to this feature, analyzing the design strategy of Rossi as an alternative to historical approaches [8].

Writer Italo Calvino offers his metaphysical artistic version of the history of the place in his work "Invisible Cities". The author writes: "In the "Invisible Cities" you will not find recognizable cities, only fictitious cities": "Thin Cities", "Cities and Eyes", "Trading Cities"... [9]. It is a search for a "different reality", where cities are presented as integral, continuous and artistically perfect. The book "Invisible Cities" is a vivid example of the displacement of the primary reality (historical facts) by the secondary "semiotic" reality, the reality of the text.

\section{THE ARTISTIC DIMENSION OF THE MODERN URBAN ENVIRONMENT: MEETING REALITIES}

The meeting of the reality of continuing tradition and the reality of the new is dramatic, always frightening in its unknown. Such encounters are painful in both the material and mental spaces. It seems that a person needs one more "reality" - a butt, connecting one that allows him to try on meanings, adapt to innovations, and become a true participant in urban history. This is the reality of "comprehension", the living environment of a changing image. Of course, the main "place" of its implementation is the consciousness and the processes of cultural transformations, but it is also possible to materialize it in the architectural and artistic environment of the city.

So, turning to the problem of realities, which is closely related to the qualities of the reliability of the environment, its historical and cultural truth, we come to the need for its enlargement beyond the boundaries of space-time measures, i.e. to the ideas of super-realities. In the spectrum of such views, not only utopian constructions are notable, but also logical ones. For example, the idea of "hyperreality" by Jean Baudrillard involves the fusion of the natural and man-made world with virtual reality [10]. The concept of the philosopher was fully accepted by Jean Nouvel, as eloquently evidenced by their joint "Louisiana Manifesto", as well as the main message of the architect's works: "All modern art is abstract in the sense that it is imbued with an idea much more than with the imagination of forms and substances" [11]. It is important to look beyond the limits of materiality.
M. R. Nevlyutov, exploring the work of Nouvel, comes to the conclusion that "architecture is described through hyperreality, its fate is always to go beyond its limits" [12].

In his turn, A. G. Rappaport in his work "The Imaginary and the Real" [13] raises three layers of reality. The first is nature that does not depend on the will of man. The second nature is the totality of things produced by man. The third nature is imaginary (and depicted), resembling the world of spirits. Here, it is appropriate to recall the scientist's idea of an evolutionary transition to an architectural "substance" [14], including, together with the accepted space-time measures, the motives of emotions, atmospheric plans, facets and motives of personal contact of the author with the work.

In the context of the system of architectural creative work, one of the timely and productive generalizing methods is the concept of art integration ("The concept of art integration in contemporary architecture", a dissertation for the degree of Doctor of architecture, defended by the author of this text in 2014 [15]), in which the idea of the "field" as a metaphor of complex interactions and mutual influences, the variability and instability of architectural phenomena became the link. According to the concept, a system of "fields" of art integration was introduced: spatial-temporal, artistic, personal. Art integration in architecture is understood as a combination of multidimensional processes of creation or reconstruction of architectural and artistic integrity, taking into account aesthetic values and guidelines. In the projection of the historical environment, the field of artistic integration determines the creation of integrity, i.e. the mutual expression and consonance of the part and the whole: a separate object and an ensemble, the author's view and objective cultural meanings, matter and the "spirit of the place".

In the spatial-temporal field, the field of contexts, space, time and human perception are inextricably intertwined. One is expressed in the other according to the principle of integrity, so the proposed selection of components is of a conditional methodological nature. Space and time "meet" in an architectural form that fixes up the style, the concept, the language of an individual architect and the era as a whole. It is the form, in this integral perspective of perception, that is the tangible result of the architect's creativity and the material message to the recipient - real and potential. Thus, it is quite natural to consider 
architecture as a collective "form" of time - the embodiment of the artistic "chronotope".

The" field" of spatial-temporal integration is spreading in the system of a city, which is at the same time a constantly updated environment of social action, multidirectional professional interests and creative aspirations. From the perspective of the multi-temporal context of the historical city, the concept of "Genius Loci" ("Spirit of Place") in the unity of the identity of space and the archetypes of its perception, referring to the unconscious mechanisms of memory, serves as an integrative basis. The field of interaction includes both material artifacts and traces of past eras, as well as spiritual categories, religious and ideological values, and standards of behavior. The integrity of the perception of history and modernity, supported by intellectual and sensual reflection in art and architecture, becomes an indicator of the culture of society. It is impossible to imagine a city without a developed communication structure that exists at all levels of life. Art integration helps forming the concept of dialogue at the symbolic level using tradition, sign, game, as well as in the aesthetic aspects of architectural modernization.

\section{ENVIRONMENTAL REALITIES OF THE CITY}

Thus, in the context of a historical city, shifting the emphasis from the content of the components to the process, when the concept of "environment" gives way to the idea of "environmental connection" based on art integration, becomes an important methodological action. As illustrative examples, there are annual festivals (or biennales) of contemporary art, city festivals, exhibitions or other cultural events, in the course of which the environment is often rediscovered by its seemingly daily user. A kind of "invention" of value by incrementing previously nonexistent ties may be considered another indicative trend. For example, preservation of an unremarkable painting of the XIX century in the interior of the building of the New Museum in Berlin during reconstruction (D. Chipperfield, D. Herrep) caused its "museum sounding" in the context of the new artistic mythology of the reconstructed space ("Figure 1" and "Figure 2").

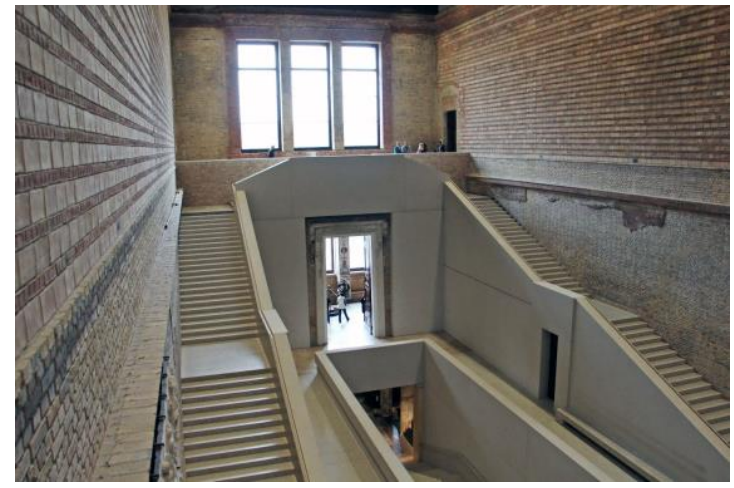

Figure 1 The New Museum in Berlin, architect D. Chipperfield, 2009. Main staircase.

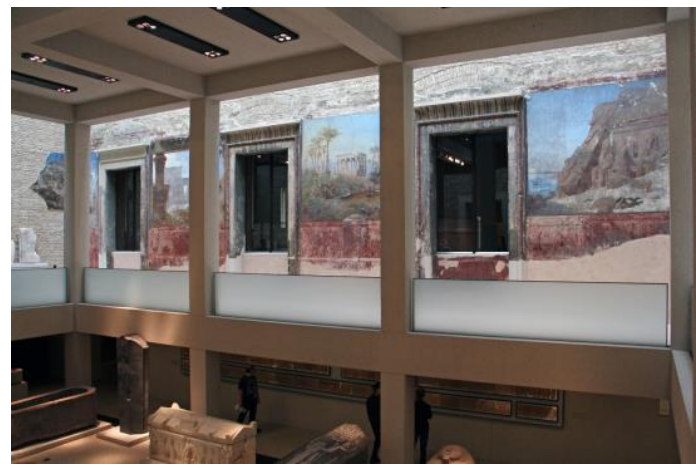

Figure 2 The New Museum in Berlin, architect D. Chipperfield, 2009. Saved murals. 
Of course, connecting the contrasting by their origin "myths" sometimes causes controversial, even curious situations. For instance, the environment of Maastricht (the Netherlands) is integral in its historicity, poetically rhyming the old and the new, attractive and convincing of the absolute truth of its reality, however, it does not prevent it from becoming a place of very bold and largely controversial initiatives. The program of renovation of religious buildings may seem to be an unexpected and even provocative step: church buildings are leased to various organizations with the condition of restoration of valuable heritage. The quality of the restoration work is doubtless; however, such functional freedom and free interventions of the current design at the moment are surprising, even shocking. We meet the hotel lobby integrated into the Baroque interior, made in a game style: a digital "funnel" of the entrance, fancy lamps, fashionable fluorescent colors and interactive "deceptions" ("Figure 3" and "Figure $4 ")$. The hotel rooms are located in the adjacent building in the former cells, and the church yard has been turned into a fun public space. Another example is more moderate, it is a bookstore-library, where the structural basis is made up of shelves, and where concentration and silence reign. In both examples, the same compositional principle is used: construction of a self-supporting structure in the central nave on the principle of a bookcase filled with new functions. Despite of some doubts about ethical aspect, such a renovation is a valuable experience, since it has already allowed to restore the architecture and paintings of cathedrals in the conditions of financial difficulties of the owner, i.e. the church. On the other hand, an experiment in meeting different-time plots in the conditions of real urban scenarios was implemented. Time will show how this is justified.

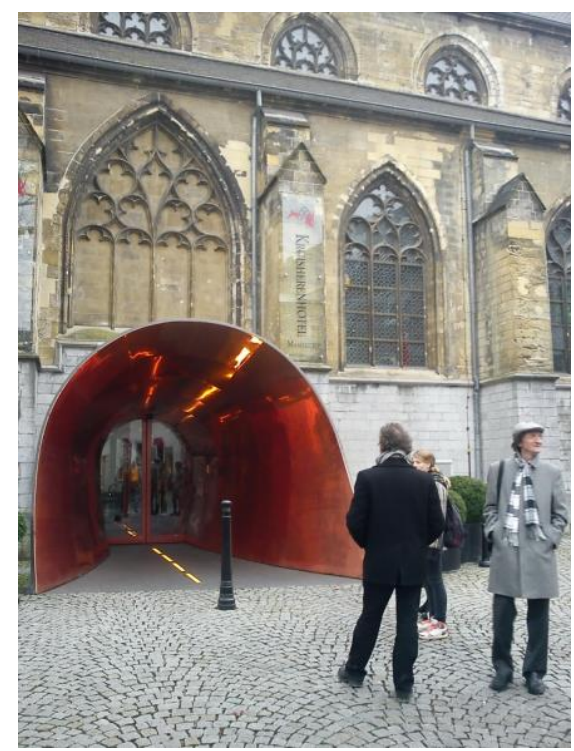

Figure 3 Maastricht (the Netherlands). Renovation of religious building: hotel. Street view.

Photo by M. V. Dutsev, 2012

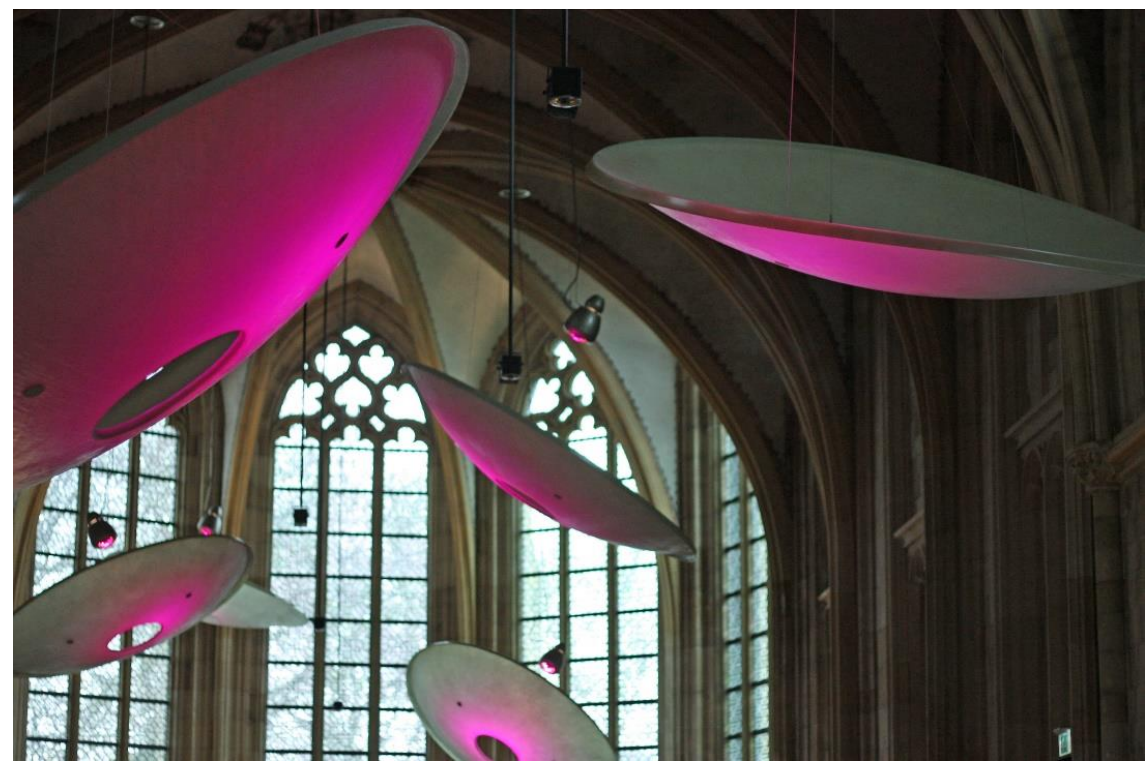

Figure 4 Maastricht (the Netherlands). Renovation of religious building: hotel. Interior. 
These initiatives are far from indisputable, are partly temporary in nature and may conflict with truly valuable works that belong to eternity. Here we need another seemingly obvious, but so rare quality - the cultural maturity of society. Today, a number of new features can be seen behind this faceless formulation. One of them is individualization within the mass market. This trend is interesting, first of all, from the position of an individual - whether it is an architect, designer, artist or a recipient of a creative message. The choice of a person's own trajectory of understanding is very noticeable on the Internet, when each user personally forms the field of his preferences. The questions, how the criteria apparatus works in this case and what the place of the hypothetical expert community is, are open.

In the larger context, this line generates the current trend of glocalization at the intersection of the achievements (or misconceptions) of the global world and local cultural traditions [16]. This trend is attractive in the context of the renovation of the historical fabric of the city, taking into account its vulnerability, not only physical, but also figurative. Delicacy and friendliness to the environment are the properties of difficult-to-achieve harmony. The modern environment of Barcelona can serve as an example of a number of successful combinations of functions, times, and author's styles. Preservation of pipes of the former boiler houses in the courtyard spaces of the reconstructed blocks was a beautiful gesture that allowed not to lose the identity. The new environment additions follow global trends, but inherit the character of the place's atmosphere. For example, Sant Antoni - Joan Oliver Library is a tiny object, but it has an important integral message ("Figure 5" and "Figure 6"). It is no coincidence that its authors, the Catalan bureau RCR Arquitectes, Rafael Aranda, Carme Pigem and Ramon Vilalta, won the Pritzker Prize in 2017 for the sum of achievements in the implementation of the glocal approach.

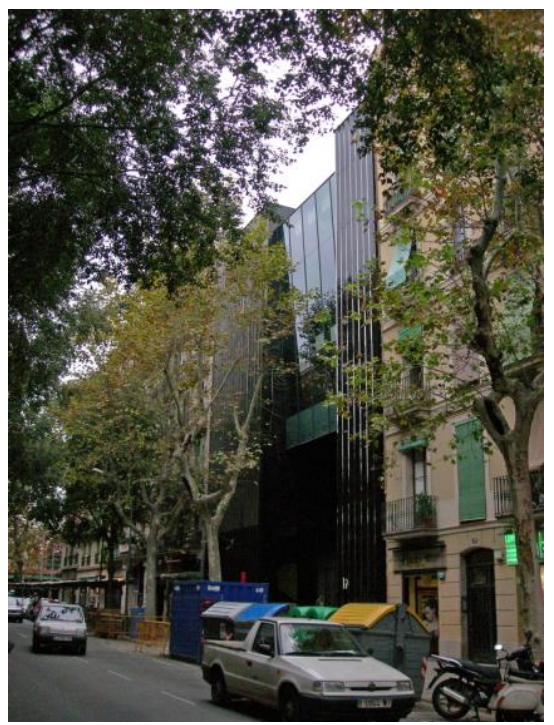

Figure 5 Library of San Antonio - Joan Oliver in Barcelona. RCR Arquitectes, 2007, in an urban environment.

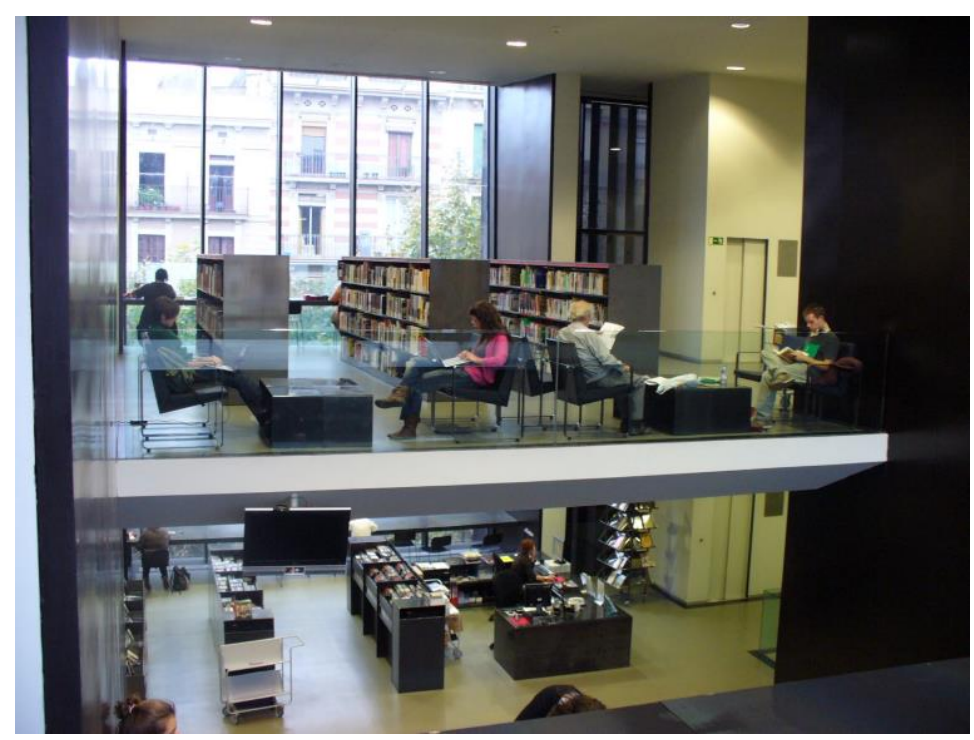

Figure 6 Library of San Antonio - Joan Oliver in Barcelona. RCR Arquitectes. 2007. Flowing and transparent space. 
The library is a good example of implementation of a number of modern trends in organization of the media space, focused on various social needs. Occupying a small plot, even playing the role of an inserted house on the street front, the library represents a mini-cultural center with a developed functional program: main funds and reading rooms, information and exhibition areas, a specialized children's section. In addition, a club for the elderly is adjacent directly to the library on the first floor. The integration of social functions is obvious. The architectural solution is characterized by the utmost openness: the entire volume of the building is literally visible through, vertically and horizontally. The urban environment freely enters the interior, which is facilitated by the use of large glazing planes, including gaps between the steps of the "amphitheater". The integrity of the architectural image is achieved by using a monochrome color scheme. The special charm of the architecture is given by the unity of the artistic theme in the solution of the interior and exterior: the austerity, elegance and permeability of the original vertical blinds. Thus, the library appears as a democratic space within the city, with a strong plastic structure, memorable, and at the same time dissolving in the historical urban environment.

\section{CONCLUSION}

So, what is the reality characterized by? In addition to the physical reality of our existence, there are many realities that a person lives in - the realities of consciousness, sensation, and artistic image. There are undeniable social, political, and economic realities that determine many things, but still cannot fully claim to explain or replace the reality that the human spirit is looking for ... In addition, we can assume realities outside of a man. So, the reality of the city is more than multicomponent, and its time dimensions are difficult to determine. In the context of asserting something real, there is always a desire for truth, a state of truth that determines a person's trust in the environment. It seems that the success of work in the historical environment is largely achieved by creating such an environmental configuration of elements, such a ratio of measures, in which several different realities can co-exist in a coherent and natural way. The bearer of each reality does not lose in its truth, and the subject does not experience a sense of deception. This can equally be attributed to the pragmatic side of the events (functional content, convenience and versatility of user scenarios), and to the artistic and figurative component, which does not tolerate "forgery".

The "poetic" or even "musical" setting of the historical space cannot be one-time, accepted once and for ever. The environment of the city is mobile, and the image of the historical place is most vulnerable, unstable, short-lived. The society's attention is often focused on specific valuable objects, endowed with the appropriate status and having a tourist, i.e. commercial attractiveness. However, a separate restored monument is not able to "hold" the environment - the environment is always larger and more complex. Here it would be appropriate to make a somewhat risky thesis that the society's understanding of culture can also be an object of "restoration", "reconstruction" or "modernization": not only in terms of calling for the preservation of memory or cultural identity, but also in terms of increasing attention to the urban organism and accepting its generic complexity. We are talking about a special "attention", an inner look, sincere, prepared, and wise.

The proposed integrative model is in many ways only a logical construction that allows to check how well the updated environment is, whether there has been a loss of important components, both material and non-material. For example, in the historical and cultural aspect, this reality collects traces of history and the spirit of the place, not allowing the accumulated memory to fade away. In the architectural and artistic experience, it promotes integration of architecture, design and art and allows the imaginative principle to live, or different aesthetic forms and their interpretations to coexist. In the social dimension, it defines the universality of the environment without loss of targeting. A special meaning is attached to the individual reality, mediating the truth of the "imprint" of the environment in the mind of the author or a recipient. The environmental activation of the city's reality is carried out at the intersection of the author's personal mythology and the collective memory of the place. This action requires from each participant a special level of preparation and the most sincere mode of responsiveness, a developed emotional beginning and a kind of environmental empathy.

Thus, the metaphorical sequence of environmental realities can be built on the principle of moving from historical authenticity, through a number of social interactions (performative, interactive, participatory, game) and artistic fields, to the author's reality of the architect or to the 
user's personal view of the environment. The multitudes of individual worlds constitute the extended mythology of reality in the mental space. Here we can also identify levels of preservation of the historical, or rather, the scope of the environment that fall into the field of professional activity and generate a real-life history of the place:

- the city as a structure and as an image, including fragments, urban ensembles, and multi-temporal layers;

- architectural objects as carriers of historical myth;

- environmental memory activators in the urban environment.

\section{AUTHORS' CONTRIBUTIONS}

This paper is independently completed by Mikhail Dutsev.

\section{REFERENCES}

[1] A. Gelfond, The territory of the Strelka of the Volga and Oka rivers in Nizhny Novgorod. Looking for the addressee, in: Proceedings of the 2nd International Conference on Art Studies: Science, Experience, Education (ICASSEE 2018), pp. 337-344. URL: https://www.atlantis-

press.com/proceedings/icassee-18

[2] A. Rossi, The Architecture of the City (Arkhitektura goroda), translated from Italian by A.M. Golubtsov. Moscow: Strelka Press, 2015, pp. 22 [in Russian]

[3] M.V. Dutsev, Art and the city environment in the flow of life (Iskusstvo i sreda goroda $\mathrm{v}$ potoke zhizni), in: Contemporary World's Architecture (Sovremennaia arkhitektura mira), vol. 9. Moscow, Sankt-Peterburg: Nestor-Istoriya, 2018, pp. 155-180 [in Russian]

[4] G. Boehme, "Atmosphere" as a fundamental concept of new aesthetics ("Atmosfera" kak fundamental'noe poniatie novoi estetiki), revised 01.01.2018, in: Metamodern. Magazine about Modernism (Metamodern. Zhurnal o modernizme). URL: http://metamodernizm.ru/atmosphere-and-anew-aesthetics/_[in Russian]

[5] V. Benjamin (Autor), Yu.A. Zdorovy (Eds.), The work of art in the era of its technical reproducibility. Selected essays (Proizvedenie iskusstva $\mathrm{V}$ epokhu ego tekhnicheskoi vosproizvodimosti. Izbrannye esse). Moscow: Medium, 1996 [in Russian]

[6] O.A. Krivtsun (Eds.) Artistic aura: origins, perception, mythology (Hudozhestvennaia aura: istoki, vospriiatie, mifologiia). Moscow: Indrik, 2011 [in Russian]

[7] M.V. Dutsev, Architectural and artistic environment as an actual history of a person (Arkhitekturno-khudozhestvennaia sreda kak aktual'naia istoriia cheloveka), in: Art and Culture Studies, no. 4 (31), 2019, pp. 30-35. [in Russian]

[8] P., Eisenman, Ten canonical buildings, 1950 2000 (Desiat' kanonicheskikh zdanii, 1950 2000). Moscow: Strelka Press, 2017, p. 184 [in Russian]

[9] I. Calvino, Invisible cities (Nevidimye goroda), translated from Italian by $\mathrm{N}$. Stavrovskaia. URL: https://www.litmir.me/br/?b=116130\&p=1 [in Russian]

[10] I.A. Dobritsyna (Eds.), Issues of the theory of architecture. Architecture: modern experience of professional self-reflection. Proceedings of the Ninth and Tenth Ikonnikov readings (Voprosy teorii arkhitektury. Arkhitektura: sovremennyi opyt professional'noi samorefleksii Sbornik nauchnykh trudov i dokladov na Devyatykh i Desyatykh Ikonnikovskih chteniyah). Moscow: LENAND, 2017, p. 401 [in Russian]

[11] Ibid., p. 300

[12] Ibid., p. 309

[13] Ibid., p. 403

[14] A.G., Rappaport Space and substance. Part 1. From function to space (Prostranstvo i substanciia. Ch. 1. Ot funktsii k prostranstvu), Academia. Architecture and construction (Academia. Arkhitektura i stroitel'stvo), 2 (2012) 20-23. [in Russian]

[15] M.V. Dutsev, The art integration in contemporary architecture, Arquitetura Revista, vol. 13, 2 (2017) 86-99.

[16] E.V. Danilova, Non-canonical architecture: to the concept of glocality (Neikonicheskaia arkhitektura: k koncepcii glokal'nosti), Architecture and Construction of Russia (Arkhitektura i stroitel'stvo Rossii), 2 (2018) 42-47. [in Russian] 